\title{
Audit as an Element of Public Governance
}

\author{
MYKOLA P. POPOV*1, LIUDMYLA L. PRYKHODCHENKO², OLENA V. LESYK ${ }^{3}$, OKSANA V. \\ DULINA ${ }^{4}$, OLESIA V. HOLYNSKA ${ }^{5}$ \\ 1,2,3,4 Department of Public Administration and Regional Studies, ODESSA REGIONAL INSTITUTE FOR PUBLIC \\ ADMINISTRATION OF THE NATIONAL ACADEMY FOR PUBLIC ADMINISTRATION UNDER THE PRESIDENT OF \\ UKRAINE, UKRAINE. *E-mail: mp-popov6111@uohk.com.cn \\ ${ }^{5}$ Department of Economic and Financial Policy, ODESSA REGIONAL INSTITUTE FOR PUBLIC ADMINISTRATION OF \\ THE NATIONAL ACADEMY FOR PUBLIC ADMINISTRATION UNDER THE PRESIDENT OF UKRAINE, UKRAINE
}

\begin{abstract}
The article considers some aspects of the implementation of the audit system of public administration, taking into account the transformation processes of national socio-economic systems, taking into account the domestic realities of society. At present, Ukraine is on the path of transition to European integration processes, including in the system of reorganization of public power. An effective mechanism for controlling and monitoring the implementation of management functions is the introduction of public administration audit. However, for Ukraine such processes are new and require adjustment of regulatory and legal support, organizational structures, financial support and managerial transformations in the public sector system in order to implement an effective public audit system. The article considers the theoretical aspects of public audit, which define it as a management process of high public importance. In addition, public administration audit is defined as a type of professional activity that requires taking into account not only the general principles of auditing, but also the specifics of public administration: publicity, high social significance, political and economic lobbying processes. Objects of public audit are considered, their characteristic is given. As a result of the analysis, the priority of conducting a public audit is determined in the system of planning, formation and distribution of budget funds at different levels. A model of public audit of budget processes has been developed and described, which provides not only control of expenditures, but also their rationalization by improving management mechanisms. Problematic aspects of the implementation of public audit in practice will be the subject of further research. The audit will contribute to the rationalization of the use of budget funds, the establishment of an effective set of management processes.
\end{abstract}

Keywords: public audit, budgeting, mechanisms of public administration, public administration, audit of public administration.

JEL Classification: H82, H83, M42, D73. 


\section{Introduction}

In the context of the transformative processes of the national public governance system related to the transition to the European vector of development, new challenges and public demands for public authorities, the implementation of effective public governance mechanisms is an important aspect. According to Transparency International Ukraine, the rating of Ukraine among other countries of the world in terms of corruption is high. The country took 126th place in the ranking of assistance to corruption in 2019 from 180 countries participating in the rating (Corruption perception index..., 2019). Such indicators affect negatively the development of the economy, ensure the high social standards, create of conditions for business development, slow down international cooperation and attract foreign investors to the country. The effectiveness of public governance mechanisms under the high corruption risks is reduced significantly or even leveled (Efremova et al., 2019; Khadzhyradieva et al., 2020a; Khadzhyradieva et al., 2020b). Thus, the implementation of the system of control of financial support of the public and private sector in the aspect of the implementation of public governance mechanisms is an urgent issue for Ukraine. The decline in the efficiency of financial processes at the level of public governance is also due to the inefficient use of financial resources due to the imperfection of management systems, the hierarchy of subordination, planning and reporting for the use of budget funds at various levels, the low level of financial literacy of the population, representatives of local councils and local officials. Therefore, in the context of poor financial policies of the state and high levels of corruption, the implementation of an audit system as part of the implementation of public governance powers at different levels is an important aspect.

Public audit issues were considered in the works of domestic scientists who devoted their research to the development of the public governance and administration system. In particular, L. Parker, K. Jacobs and J. Schmitz defined the objectives and economic basis for conducting a public audit (Parker et al., 2019). The theoretical foundations of public audit as an element of the public governance system are defined in the work of G. Brandon, C. Leuz and M. Maffett (2015). C.J. Cordery and D. Hay (2019) identified the main problems of implementation audit in public institutions, hindering the development of controlling and monitoring processes, primarily financial costs. V. Koval, K. Nazarova, V. Hordopolov, T. Kopotiienko, V. Miniailo and Yu. Diachenko (2019) considered the issues of retrospective analysis of approaches to the implementation of the public governance audit system. D. Aobdia (2019), J. Pierre and J. de Fine noted the role of public audit in the public governance system, and concerned a matter of modernization of management systems to ensure the effective implementation of auditing mechanisms in the public sector (Pierre and de Fine Licht, 2019). Audit as an element of the controlling system and the management process is sufficiently developed in the scientific works of domestic and foreign scientists (Kostruba, 2018). However, the features and specifics of the implementation of public governance audit processes are not sufficiently developed taking into account the changes and transformations taking place in Ukraine.

\section{Materials and Methods}

The relevance of audit issues in the public governance system was determined by the purpose of the article, which is to develop certain aspects of improving the efficiency of auditing in the implementation of the management function at the public sector level. For the purposes of the article, the following tasks are identified: to determine the role of public audit in the development of socioeconomic processes; to define public administration audit processes theoretically; to prioritize the implementation of public audit; to develop a model of implementation of public audit taking into account functional processes of public systems; to identify problematic aspects of implementation of the public audit system. In the context of the transformative processes of the modern socio-economic system in Ukraine, the public governance sector has new requirements to ensure the effective functioning of state institutions. The rationale for the basic elements of the audit and its implementation into the public governance system is precisely aimed at improving the efficiency of 
management processes and their effectiveness in the public sector. Therefore, it is useful to determine the main directions of public governance audit and the mechanisms for its implementation in practice.

One of the most pressing problems in public governance is the allocation of financial resources and their effective use. Therefore, the subject of the study is the financial and economic processes in the public administration system. The main hypothesis of the article is the statement that the development of audit processes for financial activities is an opportunity to create an effective, transparent system of distribution and use of public finances. The analysis of audit processes is associated with the direct development of mechanisms to improve the efficiency of financial activities in the public sector. The audit processes in this case are considered as financial monitoring and analysis of the performance of financial activities in the public administration system. Also, the audit process is seen as an important element of the public sector management system, which can even be viewed from the point of view of a separate function of public administration. the use of audit is associated with the need to control the costs of financial resources, analyze their intended purpose, as well as develop recommendations for increasing the effectiveness of financial injections into certain state projects.

\section{Results and Discussion}

In the context of the high level of corruption and the inadequate quality of management functions at the public governance level, the streamlining of budget management processes at various levels is becoming more urgent. Budget funds are the basis for the formation of processes of socio-economic development, which is related to the following factors: budget funds provide the main social development projects in the state; the funds of the budgets of various levels are the basis for the formation of public financial policy; the public sector forms the fiscal policy of the state depending on plans to fill budgets of different levels, as well as planned budget expenditures; fiscal policies can contribute to the development of the private sector with a view to enhancing business processes to ensure social security. For further analysis, it is useful to define the essence of audit as a monitoring and control process in the public governance system (Tkachenko, 1996; Vasylieva et al., 2020). The central concept of audit is its object. Present the structure of public administration audit objects graphically (Figure 1).

Figure 1 Public governance audit objects

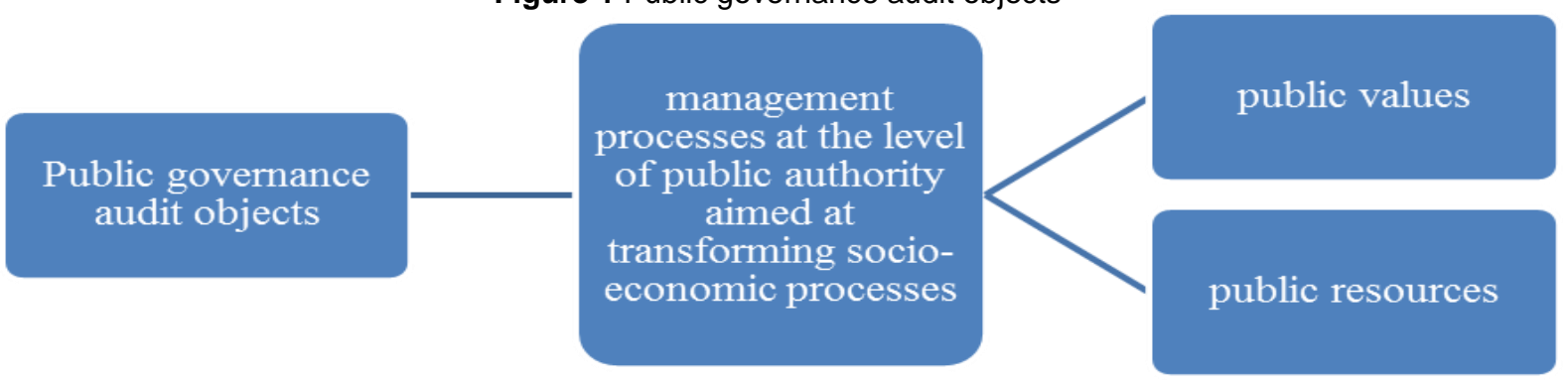

Source: Parker et al., 2019; Brandon et al., 2015.

The allocation of management objects to the values and resources of society makes it possible to determine the audit of public governance as a socially significant process (Kostruba and Vasylyeva, 2020). Public values consist of the properties of the object, which may include traditions, interests, reasons, cultural or spiritual values. The public resources of audited objects include natural, material, financial resources, as well as intellectual property and human resources. Taking into account the public role of public audit, various approaches to the theoretical definition of public governance audit can be accumulated, they are presented in the form of diagram (Figure 2). Thus, the issue of efficient and rational use of budget funds is key for the implementation of public governance functions both in the field of social guarantees and in terms of the development of the private sector of the economy. The issue of ensuring the effective and rational use of budget funds is determined in the audit process. Consider, how budget management is audited at the public governance level (Figure 3). Thus, it is determined that the basis for the formation of public governance audits is the rationalization of the use of budget funds and, as a result, the maintenance of these processes by effective management 
mechanisms. The audit is carried out primarily at the performance assessment stages, but management processes can be effectively audited at the management decision planning stages.

Figure 2 Approaches to defining public governance audits

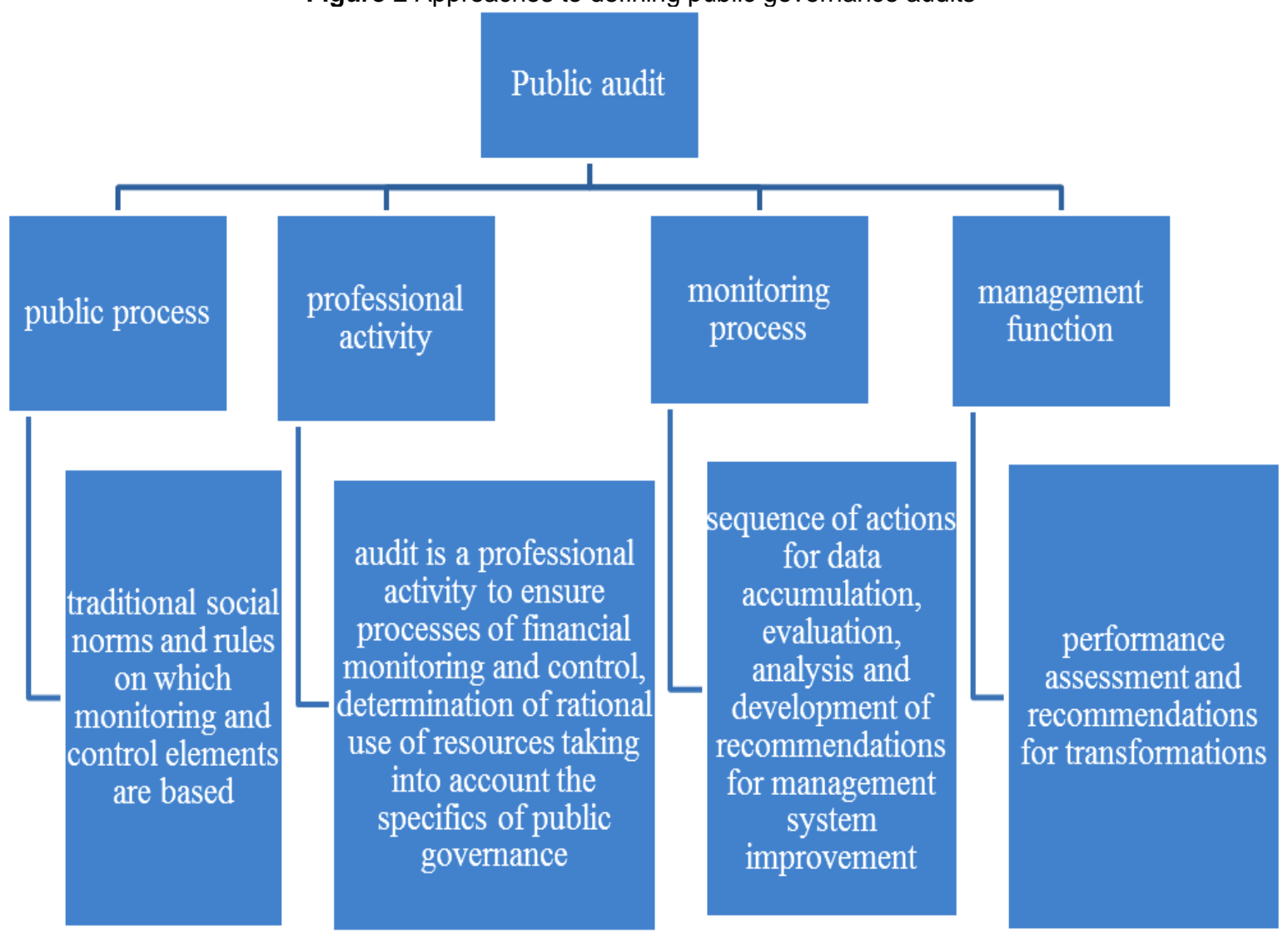

Source: Brandon et al., 2015; Duguay et al., 2019.

Figure 3 Public governance audit implementation model to the budget process

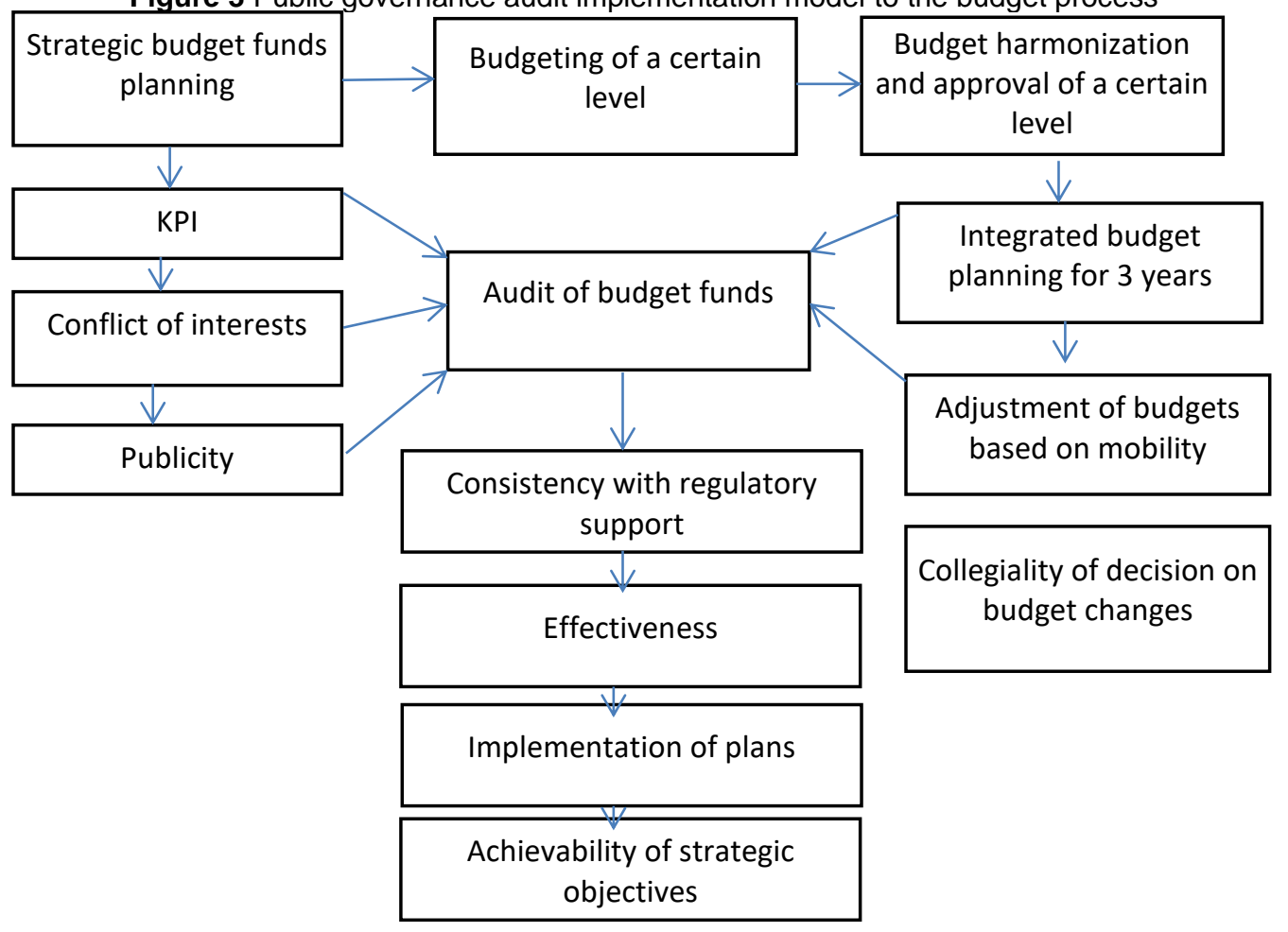


Among the features of the integrated audit system in the public governance system are the following (Pythaloka et al., 2019; Lee and Levineyu, 2020; Abu and Karim, 2021): public nature of management processes at all stages of management functions implementation; rationale of management decisions by using the data of the conducted audit; support of audit processes by information and analytical support complex. Problematic aspects of public governance audit implementation are: low qualifications or lack of specialists for public governance; lack of financial mechanisms for implementation of public governance audit processes; irrational (inflexible) organizational structure of public governance for implementation of audit processes; the reluctance of corrupt officials to implement transparent financing mechanisms, conduct independent audits, and slow down the implementation of this system.

The relevance of the issues of application and audit in the public administration system is determined by the goal, which is associated with the development of certain aspects of increasing the efficiency of monitoring and control processes, as well as ensuring the effectiveness of the adoption and implementation of the management function at the public sector level. Determining the role of state audit in the development of socio-economic processes showed that it is audit that can provide not only an increase in the efficiency of socio-economic processes in society, but also the development of social responsibility of society, public supervision of financial activities at the state level. The article theoretically defines the processes of auditing public administration as an element of the management system associated with the processes of financial control and monitoring, as well as analyzing the compliance of the planned indicators of financial and economic activity with their actual indicators, as well as analyzing the performance of financial activities at the state level. As a result of the analysis, it is possible to prioritize the implementation of public audit, first of all, as the basis for the formation of a model for conducting public audit, which is associated with the functional processes of public systems (Clara et al., 2017; Veerankutty et al., 2018; Steinberg, 2020).

The article deals with the application of audit processes in the system of public management of financial resources in order to ensure the following parameters. First, it is the control over the earmarking of the expenditure of financial resources in the public administration system, which ensures the transparency of the use of financial resources and an objective reporting system. Secondly, control over the effectiveness of financial costs in the implementation of certain projects in the public administration system, which is associated with the setting of management goals and is an element of management accounting at the level of government bodies. Thirdly, providing the results of the analysis of financial costs in order to use this information for making management decisions, which is the basis of the system of effective public administration, provides an assessment, analysis and forecasting of the consequences of such decisions (Dzomira, 2020; Ratnaningsih and Putranto, 2017).

The results of the study in the article were the definition of the features of the audit in the public administration system, which takes place under the influence of transformation processes. Changes in external factors have a significant impact on the audit processes of government agencies. Political instability, changes in the socio-political situation often lead to a biased attitude of the participants in the audit process towards its implementation. Thus, an unstable political situation can negatively affect the audit processes of the financial activities of state structures, which must also be taken into account when developing and implementing a system for monitoring and controlling financial activities at the state level. Analysis of the monitoring and control processes for the implementation of management actions, primarily in the budgeting system, is the basis for the formation of an algorithm for building an audit system in public financial management. The state audit system as an element of financial management and budgeting is an effective element of control over financial and economic activities at the state level. State audit is not limited solely to checking financial performance. The purpose of the state financial audit, and the main task, is to ensure, on behalf of the state and society, public control of the state and financial resources management system, which must be impartial and objective. Thus, the goal of government audit is to improve the efficiency of management and use of budget funds (Novatiani et al., 2018). 
The main objects of audit in the public administration system are: strategic goals, management structure and organizational structure of the public administration hierarchy, operational tasks for the implementation of business processes, innovative technologies and people. The results of the audit should have a direct impact on the following elements: task or mission, structure, technology and individuals. It is important to note the meaning of each element and the relationships existing between them - a change in one of them leads to a transformation in others. Thus, in the global understanding of audit processes, they can be considered not only as an element. An important task of state audit is to ensure control over financial and other types of resources that are used by state and municipal authorities at different levels in order to implement projects of public importance. The processes of formation and use of various types of resources are part of the planning and control elements in the public administration system. Thus, it is necessary to conduct an audit not only at the final stage of project implementation, but also to determine the rationality of resource allocation by the state already at the planning stage. Therefore, the article proposes to determine the audit algorithm in terms of control of the following functions of public administration (Abdullah et al., 2018; Hammami and Hendijani Zadeh, 2019; Vasylishyn and Yarova, 2020).

The first step is the process of planning the allocation and use of financial resources. At this stage, first, it is rational to determine the prospects of the direction for which it is necessary to allocate resources. This can be done by analyzing the audit of previous projects, and predicting the results of the current project based on the analyzed data. The planning system analyzes the cost estimate of the work, its compliance with the real potential costs for the implementation of the project, the timing of the project, as well as the possibility of optimizing the cost estimate and work schedule. The second stage of management is the organization of work processes. At this stage, it is advisable to determine how timely and in full the planned resources were received, their intended purpose and use. The control stage, the last stage that must be considered when conducting an audit of the processes of work of public authorities, provides for summing up the results of the project. At the same time, the compliance of the planned and actual indicators of its implementation is assessed, namely: expended resources (including financial), compliance with the project implementation deadlines (changes in terms can also lead to additional financial losses in the implementation of state projects), analysis of the achievement of goals and objectives, as well as quality parameters of work performance. The last point is the main one when conducting an audit, since it is this point that can show whether the goals that were originally set for the work with the allocation of funds and from the budget of a certain level have been achieved. Such an indicator will become the basis for the effectiveness of the work of public authorities and the basis for an audit opinion on the effectiveness or inefficiency of the work performed. Also, the audit can give further recommendations for correcting those comments that were identified directly during the audit. Thus, the following parameters are the result of the audit. First, an analysis of the rationality of setting plans and objectives in the public administration system. Secondly, the provision of the necessary resources and on time for the implementation of the project. Thirdly, control over the implementation of each individual task, the achievement of goals in general, the timing and resources spent on the implementation of the project. Fourthly, audit becomes the basis for the formation of relevant information about the need to make adjustments to management processes in case of their low efficiency, or in order to increase the efficiency of these processes, carry out mobile transformation when conditions change external or internal environment, for example, socio-political or social economic processes (Heald, 2018; Sari et al., 2017; La Rosa et al., 2019).

Responsibilities for auditing can be assigned to private audit or consulting companies, employees of control and audit services, invited experts and analysts who have experience in the specialized field (for example, when it comes to highly specialized audit, when it is necessary to conduct it with taking into account the specifics of the project), representatives of financial, banking and insurance companies of all forms of ownership, as well as representatives of communities, public organizations and other stakeholders, which ensures transparency and impartiality of the audit of the financial activities of state bodies. The article also identified the main problematic aspects of conducting a state audit in the system of national public administration, such as socio-economic and socio-political 
changes, a high level of bureaucracy and a corrupt component, the absence of highly specialized employees who are able to assess and analyze specific categories of work in within the framework of government projects. The solution of these and other problematic aspects of the development of public audit issues at the national level will be the subject of further scientific research.

\section{Conclusion}

Therefore, as a result of the study, the specifics of auditing in the public governance system were determined. In the context of transformation processes, the issues of monitoring and controlling the implementation of management processes, primarily in the budgeting system, are becoming increasingly important. The government audit system is considered as an element of monitoring financial and economic activities at the state level. Also, audit processes are considered as an assessment of the effectiveness of financial costs for the implementation of a project. In addition, audit is the basis for providing relevant information for making management decisions and monitoring the progress of its implementation.

In the context of transformational processes, issues of monitoring and control of the implementation of management processes, primarily in the budgeting system, are of increasing importance. The audit will help rationalize the use of budget funds and establish an effective set of management processes. Also, the main problematic aspects for the production of public audit in the system of national public governance were identified, the solution of which will become the subject of further scientific research.

\section{References}

1. Abdullah, R., Ismail, Z., \& Smith, M. (2018). Audit committees' involvement and the effects of quality in the internal audit function on corporate governance. International Journal of Auditing, 22(3), 385-403.

2. Abu, N., \& Abd Karim, M. Z. (2021). Is the relationship between corruption and domestic investment non-linear in Nigeria? Empirical evidence from quarterly data. Estudios De Economia Aplicada, 39(3), 1-18.

3. Aobdia, D. (2019). The economic consequences of audit firms' quality control system deficiencies. Management Science, 66(7), 2883-905.

4. Brandon, G., Leuz, C., \& Maffett, M. (2015). Public audit oversight and reporting credibility: evidence from the pcaob inspection regime. The Review of Financial Studies, 33(10), 4532-79.

5. Clara, A.M.C., Canedo, E.D., \& De Sousa Júnior, R.T. (2017). Elements that orient the regulatory compliance verification audits on ICT governance. ACM International Conference Proceeding Series, Part F128275, 177-84.

6. Cordery, C.J., \& Hay, D. (2019). Supreme audit institutions and public value: demonstrating relevance. Financial Accaunting and Management, 35(2), 128-42.

7. Corruption perception index (2019). https://ti-ukraine.org/research/indeks-spryjnyattyakoruptsiyi-2019/ [Accessed Jan 20, 2021].

8. Duguay, R., Minnis, M., \& Sutherland, A. (2019). Regulatory spillovers in common audit markets. Management Science, 66(8), 3389-411.

9. Dzomira, S. (2020). Corporate governance and performance of audit committee and Internal audit functions in an emerging economy's public sector. Indian Journal of Corporate Governance, 13(1), 85-98.

10.Efremova, E.I., Fedchenko, E.A., Kurashova, A.A., Shevereva, E.A., Bondarchuk, N.V., \& Lashchinskaya, N.V. (2019). Methods of assessing feasibility of involvement of the audit organization in the public procurement. Journal of Advanced Research in Law and Economics, 10(8), 2327-34. 
11.Hammami, A., \& Hendijani Zadeh, M. (2019). Audit quality, media coverage, environmental, social, and governance disclosure and firm investment efficiency: Evidence from Canada. International Journal of Accounting and Information Management, 28(1), 45-72.

12. Heald, D. (2018). Transparency-generated trust: The problematic theorization of public audit. Financial Accountability and Management, 34(4), 317-35.

13.Khadzhyradieva, S., Chernenko, N.M., Larina, N.B., Ruchkina, M.M., \& Sakaliuk, O.O. (2020a). Risks in public administration in the context of globalisation. International Journal of Criminology and Sociology, 9, 2921-8.

14.Khadzhyradieva, S., Docsenko, T., Sitsinska, M., Baiun, Y., \& Pukir, Y. (2020b). Prerequisites for process management implementation in the public administration of Ukraine. International Journal of Criminology and Sociology, 9, 2825-33.

15.Kostruba, A.V. (2018). The place and role of right depriving legal facts in the legal regulation mechanism of civil property relations. Utopia y Praxis Latinoamericana, 23(82), 171-83.

16.Kostruba, A.V., \& Vasylyeva, V.A. (2020). Termination of right in the mechanism of civil legal relations. Rivista di Studi sulla Sostenibilita, 2020(1), 287-300.

17.Koval, V., Nazarova, K., Hordopolov, V., Kopotiienko, T., Miniailo, V. \& Diachenko, Yu. (2019). Audit in the state economic security system. Management Theory and Studies for Rural Business and Infrastructure, 41(3), 419-30.

18.La Rosa, F., Caserio, C., \& Bernini, F. (2019). Corporate governance of audit firms: assessing the usefulness of transparency reports in a Europe-wide analysis. Corporate Governance: An International Review, 27(1), 14-32.

19.Lee, K.K., \& Levineyu, C.B. (2020). Audit partner identification and audit quality. Review of Accounting Studies, 25, 778-809.

20.Novatiani, R.A., Afiah, N.N., Soemantri, R., \& Ritchi, H. (2018). Internal audit function and application of good corporate governance at public Indonesian commercial banks. European Research Studies Journal, 21(S3), 381-8.

21.Parker, L.D., Jacobs, K. \& Schmitz, J. (2019). New public management and the rise of public sector performance audit: Evidence from the Australian case. Accounting, Auditing and Accountability Journal, 32(1), 280-306.

22.Pierre, J., \& de Fine Licht, J. (2019). How do supreme audit institutions manage their autonomy and impact? A comparative analysis. Journal of European Public Policy, 26(2), 226-45.

23.Pythaloka, D.A., Rosnidah, I., \& Sulistyowati, W.A. (2019). The influence of company size and audit fee on audit quality. Advances in Economics, Business and Management Research, 65, 371-5.

24.Ratnaningsih, R., \& Putranto, R.A. (2017). Impact of auditor independence and good corporate governance companies on the quality audit (studies in public accountant firm in east Jakarta). International Journal of Economic Research, 14(17), 193-201.

25.Sari, N., Ghozali, I., \& Achmad, T. (2017). The effect of internal audit and internal control system on public accountability: The emperical study in Indonesia state universities. International Journal of Civil Engineering and Technology, 8(9), 157-66.

26.Steinberg, F. (2020). Global economic governance: where do we stand? Estudios De Economia Aplicada, 32(3), 891-910.

27.Vasylishyn, S., \& Yarova, V. (2020). Analytical provision of socio-economic security management at macro and microlevels. Estudios De Economia Aplicada, 38(4), 1-11.

28.Tkachenko, A.A. (1996). Criteria of depressed status of a region. Vestnik Moskovskogo Universiteta, Seriya 5: Geografiya, 4: 66-71.

29.Vasylieva, O.I., Slukhai, S.V., Khadzhyradieva, S.K., Klochko, A.A., \& Pashkova, A.G. (2020). Ukrainian civil service: implementation of the public administration reform strategy in Ukraine. Journal of Advanced Research in Law and Economics, 11(4), 1439-45. 
30.Veerankutty, F., Ramayah, T., \& Ali, N.A. (2018). Information technology governance on audit technology performance among Malaysian public sector auditors. Social Sciences, 7(8), article number 124. 